\title{
INTERGRATED ENVIRONMENTAL LAW SYSTEM STRATEGIES TO ADAPT CLIMATE CHANGE IMPACT FROM ENERGY RESILIENCE IN INDONESIA ${ }^{\Omega}$
}

\author{
Maret Priyanta \\ Faculty of Law Universitas Padjadjaran, Indonesia \\ E-mail: maret.priyanta@unpad.ac.id
}

\begin{abstract}
Climate change issues are solicitous and affect every nation due to its impact on human living and other living things. International cooperation through the international convention on climate change such as United Nations Framework Convention on Climate Change needed as an effort for finding solution for the problem especially the legal aspect. Energy as resources is identified as one of sources directly contributing to global warming. As a part of environment, energy resilience needs to support Indonesia commitment to the global society. This paper describes the academic perspective in environmental law by applying principle and norm approach to analyze the climate change issues in Indonesia related to energy resilience. The recommendation analyzes the issue based of law research with descriptive analytical methodology to describe comprehensive idea about the problem and solution in climate change issues and environmental law in Indonesia law system perspective.
\end{abstract}

Keywords: climate, energy, environmental, law, resilience.

\begin{abstract}
Abstrak
Masalah perubahan iklim sudah memprihatinkan dan mempengaruhi setiap bangsa, karena dampaknya terhadap kehidupan manusia dan bentuk kehidupan lainnya. Kerja sama internasional melalui konvensi internasional terkait perubahan iklim seperti United Nations Framework Convention on Climate Change dibutuhkan sebagai upaya untuk menemukan solusi untuk memecahkan masalah terutama aspek hukum. Energi sebagai sumber daya, diidentifikasi sebagai salah satu sumber yang secara langsung berpengaruh terhadap pemanasan global, sebagai bagian dari lingkungan, ketahanan energi perlu mendukung komitmen Indonesia terhadap masyarakat internasional. Artikel ini akan menggambarkan perspektif akademis dalam hukum lingkungan, dengan pendekatan prinsip dan norma untuk menganalisis isu perubahan iklim di Indonesia terkait dengan ketahanan energi. Rekomendasi tersebut akan menganalisa berdasarkan penelitian hukum dengan metodologi analisis deskriptif untuk menggambarkan gagasan komprehensif tentang masalah dan solusi dalam isu perubahan iklim dan hukum lingkungan dalam perspektif sistem hukum di Indonesia.
\end{abstract}

Kata kunci: ikilm, energi, lingkungan, hukum, ketahanan

\section{Introduction}

Indonesian constitution mention that one of the state responsibilities is "...to protect all aspect in Indonesia territory..." including environment from any harm causing damage for present and next generations. Global warming which causes climate change is one of the environmental problems globally including Indonesia. O'Brian ${ }^{1}$ called as War against climate change

$\Omega \quad$ This article is an article research conducted under the decisioan of the Dean of Faculty of Law, Padjadjaran University No. 122/UN6.A1/LT/2016, date April 12, 2016 show this is a serious and complicated problem mainly from development activities. Regulation and policy of the state related environmental protection and management will be very important to mitigate and or adapt the climate change source and impact.

Indonesia, from Kyoto Protocol 1997 is non-annex state, did not have any international obligation to mitigate protocol-based emission but the state responsibilities regulated in Indo-

Kevin J O'Brian, “The 'War' Against Climate Change and Christian Eco-Justice: Ethical Implications of Martial Rhetoric”, Worldviews, Vol. 16, 2012, p.135. 
nesian constitution order to protect all citizen and also natural resources from any harm to protect over time. In that perspective, Indonesia commits voluntarily to mitigate and adapt impact of the climate change based on the statement (commitment) from President Republic of Indonesia at the G-20 Leaders Summit September $25^{\text {th }} 2009$, at Pittsburgh, PA, that:

".... Indonesia has to move forward based on the principle of "common but differentiated responsibilities and respective capabilities". Both developed and developing nations must do more and do away with "business as usual" mentality. Developed nations must take the lead, but developing nations must also seriously do their part...Indonesia has done and what we will do because we also want to be part of the solution. Indonesia of course faces problems and challenges in our national development: growth, unemployment, poverty, infrastructure building, education and health care. But we have decided and established a National Climate Change Action Plan with the targets of 2020 and 2050. Indonesia are devising an energy mix policy including LULUCF (Land Use, Land Use Change, and Forestry) that will re-duce our emissions by 26 percent by 2020 from BAU (Business as Usual). With inter-national support, we are confident that we can reduce emissions by as much as 41 percent. This target is entirely achievable because most of our emissions come from forest related issues, such as forest fires and deforestation"

In 2016, Indonesia revised the national target by 29 percent by 2030 from BAU, this commitment was declared on Law 16 of 2016 on Paris Convention to the United Nations Framework Convention on Climate Change Ratification as a follow up the commitment from BAU. Law No. 32 of 2009 on Environmental Protection and Management already regulated the responsibility of state including citizen to consider climate change issues as prior concern in every activity related to natural resources management for realizing sustainable development for present and future. The regulation mentions in philosophical foundation that:

$$
\text { “...environmental quality has diminished }
$$

threaten the survival of life of humans and other living things that need to do protection and environmental management seriously and consistently by all stakeholders, that global warming resulted in an ever increasing climate change which exacerbates environmental degradation, so it is necessary for regulating environmental protection and management ..."

In 1982 when the first environmental regulation set in Indonesia, environmental policy becomes an underlying environment in Indonesia because the laws, regulations and other implementing regulations are instruments of wisdom. The environmental legislation as umbrella provision accommodates environmental policy in Indonesia. After two amendments, the provision and provision of the environmental legislation have been removed due to various regulations enactment related to environmental set after such as regulation related to forestry, plantation, energy, mining, etc.

In principle, every regulation on environment in Indonesia set a permit regulation to control every activity related to environmental management. In its implementation, many regulations are overlapping causing legal issues, such as forestry, plantation and mining regulations. In addition, arrangements on spatial planning have not been the basis for any natural resource utilization activities and decision. ${ }^{2}$

Related to mitigation of climate change, the source emission of greenhouse effect will be important to manage. This source needed to be regulated in national policy and regulation. Based on statement of president Republic of Indonesia, in case of international support, Indonesia confidently can reduce emissions by as much as 41 percent. Starting from 26 May 2010, Letter of Intent between the Government of the Republic of Indonesia and the Government of Kingdom of Norway on Cooperation on reducing greenhouse gas emissions from deforestation was signed. The purpose of the Partnership is to contribute to significant reductions in green-

2 See Baaner, Lasse and Hvingel, 2015, Line, Spatiality of Environmental Law, Journal for european environmental \& planning law, Vol. 12, p. 176. 
house gas emissions from deforestation, forest degradation and peat land conversion through: first, conducting a policy dialogue on international climate change policy, in particular international policy on REDD+; and second, Collaboration in supporting the development and implementation of Indonesia's REDD+ Strategy. ${ }^{3}$

In doing so, Indonesia formulated a regulation to fulfill the agreement. Policy and regulation was set out to implement the commitment. In Indonesia environmental protection becomes all citizen responsibility, but the state has duty and responsibility by the constitution to protect the state. Environmental conditions have significantly decreased since the development is not environmentally sustainable. The state, thus, should be able to provide solutions and emphasis on issues of environmental protection through a variety of efforts including clear formulation of legislation in either constitution, laws legislation or other implementation regulations.

Indonesia as a developed country requires every resource to fulfill the national necessity for welfare and development purposes. Management of environment today in Indonesia cause several problems to degradation quality of environment. Basically, every bussiness activity is economic-oriented. "Garret Hardin in his paper the tragedy of the common says that economic reasons move human behavior and take a decision to common property in the sense of natural resources that cannnot be claimed as individual right." 4

In principles, every bussiness activity brings environmental impact both society and environment (ecosystem perspective) that cause environment degradation. Therefore, in environmental law system, licensing mechanism is one of important instruments in environmetal law compliance system to control and assess impact possibility from bussiness activity that managed and exploited natural resources including direct and indirect influence and support

See Savaresi, "Annalisa, Forests, economics, and climate change", Climate Law, Vol. 2, 2011, p. 441.

4 Takdir Rahmadi, 2011, Hukum Lingkungan di Indonesia, Jakarta: PT. Rajagrafindo Persada, p. 8. mitigation and adaptation of climate change.

There are opportunities and challenges for Indonesia to mitigate and adapt climate change impact for sustainable development and support energy resilience. From legal aspect, some issues must be solved by government. Generally, the common challenges that Indonesia faces related to climate change issues are: first, environmental law system based climate change; second, implementation of international agreements and treaties on climate change in national law; third, harmonization and synchronization of legislation, especially in terms of natural resources that affect climate change and support energy resilience; fourth, regional autonomy and authority in the area of climate change issues; fifth, legal education environment for all communities on the importance of participation in mitigation and adaptation to climate change.

On the other hand, Indonesia is optimistic in mitigation and adaptation to climate change, to see the opportunities in law and regulation aspects and the various policies and regulations. Some of these opportunities include: first, government policy and some arrangements have existed and continue to be prepared in the context of climate change mitigation and adaptation; and second, legal regulations that have adopted the neighborhood of climate change issues, such as: Institutional formation specialized in relation to climate change; Enactment, the National Action Plan for Greenhouse Gas Emission Reduction as a climate change mitigation; environmental license mechanism systems approach to climate change mitigation; national development plans with the approach to climate change adaptation and energy support; opportunities for international cooperation with regard to climate change mitigation and adaptation.

Energy management which includes the supply, utilization and enterprise must be fairly, sustainably, rationally, optimally, and integrated carried out in order to provide added value to the economy of Republic of Indonesia. Provision, utilization, and exploitation of energy as continuous effort to improve the people wel- 
fare must be harmonious, and balanced with environmental functions. This must accommodate each interest between central and local government based on separation of power.

Energy industry in Indonesia is categoryized as a business activity. Carrying out its activities must perform a variety of permit process based on the applicable laws and regulations. In principle, every business and/or activeties is required to have Environmental Impact Assessment (EIA), especially for businesses that could potentially have an impact on environmental pollution, destruction and community. Energy based national act includes the following: petroleum, natural gas, coal, biofuels, geothermal, new energy and other renewable energy, particularly biomass, nuclear, hydroelectric, solar power, and wind power, liquefied coal, nuclear, hydrogen, coal bed methane, and gasified coal.

The energy sector also related to climate change mitigation and adaptation potential of conservation agriculture by studying effects of minimum cultivation. Cultivation operations such as moldboard plowing, chisel plowing, cultivation, and blade harrowing were omitted. This also implies that most focus energy is from the natural resources. ${ }^{5}$ Concern on the energy sector is also done in the UK, Department of Energy and Climate Change (DECC) in 2008, and focusing on domestic level to reduce greenhouse gas for mitigation on climate change. ${ }^{6}$

Increased economic competitiveness through the strengthening of the manufacturing industry is in line with the strengthening of agricultural development and the increasing development of marine and other natural resources which is in accordance with an integrated regional potential and the increase of science and technology accelerated development of infrastructure to further enhance cooperation between government and business. Improving the

5 See Ram A. Jat, Suhas P. Wani, etc, 2015, "Evaluating Climate Change Mitigation and Adaptation Potential of Conservation Agriculture in Semiarid Tropics of Southern India, British" Journal of Environment \& Climate Change, Vol. 5 No. 4, 2015, p. 332.

6 Aileen McHarg, "Climate change constitutionalism? Lessons from the United Kingdom, Climate Law, Vol. 2, 2011, p. 481. quality and relevance of education and economic institutional arrangements encourages community initiatives in economic activity. The condition is supported by the development of transport infrastructure network, post and telecommunications; increased use of renewable energy, particularly bioenergy, geothermal, hydropower, wind power, and solar power for electricity and water resource development and housing and settlement development. At the same time, the marine industry covering marine transportation, maritime industries, fisheries, marine tourism, energy and mineral resources are developed synergically, optimally, and sustainably. ${ }^{7}$ The problem of this research are: first, how do Indonesian law systems today support adaptation of climate change; and second, how do the strategy and opportunities adapt climate change from energy resilience in Indonesia.

\section{Research Methods}

This paper tried to describe law analytical description from the academic perspective in Indonesia environmental law system, with principle, norm and also implementation to analyze the main source problem of climate change especially in Indonesia. The recommendation of solution is analyzed based of law research related to the topic with descriptive analytical methodology to describe comprehensive idea about the problem and solution in climate change issues and environmental law in Indonesia law system perspective.

The law and regulation describe legal normative, systematic conducted toward the related constitution and other regulation (national and international) to obtain the conclusion and recommendation to solve climate change problem for preservation of environmental function, energy resilience and sustainable development. The analysis also explained comprehensive law problem in Indonesia and implementation in central, province, district and city on climate change issues.

\footnotetext{
Law Number 17 Year 2007 on Indonesia National LongTerm Development Plan.
} 


\section{Discussion}

Indonesia is a state law (rechtstaat), every activity that involve the public interest is regulated by law. In Indonesia, various law schools develop a concept of law in society, so that by Mochtar Kusumaatmadja defined law is not just the overall law principles and rules that govern human life in society but also includes institutions and processes which embodies those principles into effect in implementation.

Environment is essentially an ecosystem, the laws governing environmental aspects should also be viewed as a system. The legal system consists of sub-systems, sub-system of law including sub system of environmental law. The legal system is also an integrated entity which is composed of parts of completeness according to a definite purpose. Environmental Law in Indonesia includes a hierarchical provision in which the provisions of a degree that the implementation in Indonesia is regulated by Law 12 of 2011 on the establishment of legislation.

Definition of law and legal functions in society can be restored to the basic question on the purpose of the law itself. The main objective of law is order; the need for order is a basic requirement for the existence of an organized society. Man, society and the law are inseparable notion (ubi societas ibi ius)". The concept of law functions as a means to reform society in Indonesia, renewal of society through legislation. The concept of law underlying legal policy and legislation (recht politics) can be explained by terminology and modern conception or theory, but in fact the concept is established by Indonesian people themselves based on immediate need and influential factors rooted in the history of the Indonesian community and nation. ${ }^{8}$ "Accordingly, the purpose of the legal system is bound rather than the objectives contained in the law itself, namely order, balance and harmony, and justice".

The application of international law or international agreements in most developing countries, including Indonesia is slowly implemented, because many developing nations tend

$8 \quad$ Ibid., p. 10. to sacrifice environmental protection for the development interest, such as statements because of the urgent problems many developing countries face, they have been slow to adopt strict environmental laws or have been reluctant, once they adopt such laws, actually to enforce them. Lack of enforcement in developing countries indicates both lack of capacity and will as many developing countries are content to sacrifice more their environmental protection in the pursuit of their development goals.

Environmental Law includes compliance and law enforcement, which covers the state administrative law, civil law, alternative dispute resolution and criminal law. In terms of compliance with the terms have the meanings preemptive action, preventive and proactive. Preemptive action is taken at the level of decision-making and planning, preventive action is taken at the implementation level through compliance with environmental standards of waste and/or economic instruments, while proactive action at the level of production is the application of environmental standards.

Enforcement meaning especially formulated between preventive repressions exist in the form of sanctions. Because it is essentially Environmental Law emphasizes the values of legal compliance to the preservation of the environment, compared to the values enforcement. The values of compliance with the law should be given pinpointed and should be formalized into the formulation of legislation. ${ }^{9}$

Based on 1945 Constitution, "Earth and water and the natural resources contained therein shall be controlled by the state and used for the welfare of the people". ${ }^{10}$ This article discusses exploited natural resources without considering environmental impact. This article should be followed by the state responsibility as regulated in introduction (preamble) that defines State Government of Indonesia which protects all the people of Indonesia and the entire country of Indonesia and to promote the general welfare. With regard to the statement of protecting the entire nation and the country of In-

\footnotetext{
9 Ibid.

10 Indonesia Constitution 1945. Art. 33 Par. 3.
} 
donesia from the perspective of environmental law, that the state has a responsibility towards conservation and environmental protection both of human resources, natural resources and cultural resources.

In the development of environmental law in Indonesia, various factors affecting growth and development such as international conferences and international conventions, including international agreements on climate change. Various principles of international environmental law were adopted in national environmental laws such as sustainable development and climate change. Sometimes environmental management does not currently reflect justice. According to Hume, this naturalness concerns human nature. Designating basic principles of justice as 'natural laws' is valid only "if by natural we understand what is common to any species, or even if we confine it to mean what is inseparable from the species." 11

The concept of justice in Indonesia is guided by Pancasila as the state philosophy and ideology emphasizing justice for all Indonesian people. Justice in environmental aspects should be defined as fairness in the protection and management of the environment for people well-being and the environment that has given its function in supporting human life and other living creatures. Environmental justice as fairness is reflected in the statutory sector that puts the interests of the sector. So the state has a major role in delivering justice for the environment and society in the concept of Indonesian archipelagic vision (wawasan nusantara).

By climate change convention in Indonesia national law and regulation, the benefit of the environment becomes a major consideration in any decision-making for the government related to management of environment and internalization in various development sectors, such as in energy sector, forest management, natural resources, agriculture, plantation, spatial, and

11 Kenneth R. Westphal, 2010, From 'Convention' to 'Ethical Life': Hume's Theory of Justice in Post-Kantian Perspective, Journal of Moral Philosophy, Vol. 7, p. 107. infrastructure. ${ }^{12}$

Under the Kyoto Protocol to the United Nations Framework Convention on Climate Change, 1997 (the Kyoto Protocol) Indonesia actually does not belong to as annex countries which have an obligation based of convention to reduce greenhouse gas emissions, but as a country exposed to possible negative impacts of climate change, Indonesia is interested in tackling and preventing climate change. One form of the Government of Indonesia's commitment expressed by the President of the Republic of Indonesia in the Conference of the Parties (COP) 15 in 2009 held in Denmark Copenhagen, as a support for the Copenhagen Accord, the National Council on Climate Change (NCCC) sent a letter to the UNFCCC Secretariat expressed support for the ACcord and Indonesia's commitment to reduce emissions of greenhouse gas emissions 26 percent by 2020 and 41 percent with international assistance by letter dated January 19, 2010. The letter is followed by a proposal Indo-nesian official target to be attached to the Copenhagen Accord on January 27 2010, with deriving sectors that will be involved in this emission reduction initiative.

In Indonesia, environmental law policy underlies environment in Indonesia since the laws, regulations and other implementing regulations are instruments of wisdom. The nature of law on the environment as umbrella provision accommodates environmental management and protection policy in Indonesia. Within the framework of the National Environmental Law issue of global warming causing climate change is undertaken by the principles in line with the principles agreed to in various international conferences in the field of the environment: first, the principle of state responsibility that the state guarantees the right of citizens to good living environment and healthy activities and state prevents the use of natural resources that cause pollution and/or damage to the environment; second, the principle of common but differentiated responsibilities in climate change mitigation responsibilities; third, the principle

12 Ibid. 
of sustainability in which everyone assumes liability and responsibility towards future generations and towards one another in a single generation by making the effort to preserve the carrying capacity of ecosystems and improve the quality of the environment; fourth, precautionary principle is that the possibilities of impact on a business and/or activity due to limited mastery of science and technology is not a reason for postponing measures to minimize or avoid the threat of pollution and/or damage to the environment; fifth, participatory principle is that every member of the community is encouraged to play an active role in the decisionmaking process and the implementation of environmental protection and management, either directly or indirectly, this principle emphasizes public participation in environment; sixth, the principle of good governance is that the protection and management of the environment is inspired by the principles of participation, transparency, accountability, efficiency, and fairness; and seventh, the principle of local autonomy is that the government and local governments regulate and manage their own affairs in the field of environmental protection and management by taking into account the specificity and diversity of the region in the frame of the Unitary Republic of Indonesia.

Environment is a legacy for all humanity (the common heritage of mankind), so protection becomes a priority for every human being for the benefit of future generations. In the concept of sustainable development as agreed in the Rio de Janeiro Conference of 1992 putting forward the development that meets the needs of the present without compromising the ability of future generations ${ }^{13}$ to meet their own needs so ensuring environmental justice for generations to come. This conference also agrees to combat climate change as global environmental issues. ${ }^{14}$

13 See Christoph Schwarte, "The International Law Association's Legal Principles on Climate Change and Climate Liability Under Public International Law", Climate law, Vol. 4, 2014, p. 206.

14 See Yuhong Zhao, "Climate Change Mitigation-Law and Policy Development in China" Journal for European Environmental \& Planning Law, Vol. 12, 2015, p. 306.
Indonesia law system regulates the ratification of the international convention, this process face a lot of difficulties in environmental matter. Regional autonomy gives opportunity and also challenge for implementation of international convention in unity state for securing the sustainable development for present and next generation.

International convention related to climate change in Indonesia cannot be effectively applied locally and regionally for there is no regulation related to ratification through international convention related to environmental matter in law and regulation for local government referring to comply the related local policy. In order to implement sustainable development, law related to environmental protecttion and management must become the guidelines for every activities in Indonesia including compliance and enforcement environmental law related to climate change for protection environmental function for present and next generations. As a development concept, the definition and understanding of sustainable development is often deemed unclear and vague. In this regard, Bruce Mitchell, B. Setiawan and Dwita Hadi Rahmi categorize the various views on the meaning of the concept of sustainable development for developing countries as follows: ${ }^{15}$ first, prioritizing development efforts on meeting the basic needs of people today, and ensuring continuity of economic development itself; second, more emphasis on equity between generations rather than across generations; and third, developing countries are reluctant to meet the suggestions of developed countries to change their economic activities to protect the global environment. The leaders of developing countries found their people have the same right to meet their basic needs, and they should not be forbidden to do something to achieve a level of economic stability as it is now.

Indonesia unfortunately faces the problem of applying the concept of sustainable development. Fulfillment of basic human needs

15 Ida Nurlinda, 2009, Prinsip-Prinsip Pembaruan Agraria “Perspektif Hukum", Jakarta: Rajawali Press, pp. 193195. 
and sustainability of economic development relying on the availability of natural resources causes a variety of problems related to environmental issues and natural resource use. On the other hand, the meaning of the concept of sustainable development itself is not well understood by the stakeholders in Indonesia.

One of the problems in the legislation in Indonesia deals with harmonization and synchronization of regulation, especially in the field of natural resources that affect climate change. The setting of climate change issues, with regard to the ratification of the Kyoto Protocol on Climate Change is the harmonization of national policies with local wisdom in the establishment and implementation of legislation in the environmental field. A number of laws and regulations related to climate change such as environmental regulation, forestry, air pollution, and so forth spatial overlapped. In the development environment settings in Indonesian, local autonomy in governance has brought changes in the relationship and authority between the central and local governments. In the implementation, harmonization of environmental legislation must adjust form and order of law in Indonesia.

In principle legislation governing the $\mathrm{Na}$ tional Development-Regional causing climate change has been established by the government in various legislation such as Law 32 Year 2009 on the Protection and Management Environmental, Law 23 Year 2014 on local Government and its implementing rules, but the norms that govern the obligations have not been prepared specifically including regional affairs (provincial, district/city) premises in respect of climate change and energy resilience.

Legislation Harmonization Center-Regional governing National Development - the area within the framework of the Climate Change should be prepared based on the hierarchy of legislation, but the absence of a clear national norms as a source of rules with regard to the area of climate change create legal uncertainty in the conduct of the affairs by regions. Harmonization of the legal constraints on the formation and implementation of laws and regulations governing the National Development-Regional Climate Change is in the framework of rules to be used as a source of law with respect to climate change. The spread of norms regulating aspects of climate change makes local government difficult in implementing national policy on climate change.

Within the scope of the Unitary Concept Republic of Indonesia, local governments play an important role by legislation. Regional government made up of areas of provincial and district/city set by law. ${ }^{16}$ They set up and man-age their own affair according to the principles of autonomy and assistance. ${ }^{17}$ Local governance through wisdom can play an important role in anticipating the potential problems of global warming in the region.

Affairs of the provincial government and district/city with regard to climate change and protection of the atmosphere include the establishment of policies controlling the impacts of climate change, the establishment of policies and the protection of the ozone layer and acid deposition monitoring. In line with this, the international agreements in the field of environmental control, the provincial government and local governments have affairs in the implementation of international treaty commitments in the field of environmental impact control which involves validation, compliance monitoring, and documentation and dissemination and implementation of monitoring and control conventions and protocols. Within the scope of local government, environmental control should become a business function implemented by local governments.

The provincial government and district/ city affairs concerning climate change and protection of the atmosphere comprise the establishment of policies controlling the impact of climate change, the established of policies of ozone layer and acid deposition monitoring. Despite few cases related to climate change in Indonesia, there are some related to forest and energy. Preston described "in some cases challenging governmental decisions on grounds re-

\footnotetext{
16 Indonesia Constitution 1945. Art.31 Par. 1.

17 Indonesia Constitution 1945 Art. 31 Par. 2.
} 
lating to climate change, the applicants have been unsuccessful in terms of the outcome of the court's decision. Nevertheless, the cases may still have achieved some benefit in terms of affirming the need to integrate climate change issues into decision-making, highlighting areas in need of law reform, or influencing project developers to redesign projects to better address climate change issues. ${ }^{18}$

There is a regulation on development planning and regulation on spatial planning becomes an important aspect in the prevention of global warming causing climate change. Van Buuren (etc.) describes that Spatial planning has to play a vital role in implementing adaptation measures and in safeguarding the climate strength of spatial developments. ${ }^{19}$ Spatial planning aims to create national spatial safe, comfortable, productive, and sustainable knowledge based archipelago and National Security. ${ }^{20}$ In national development, the government also established the National Development System and implied in National Long-Term Development Plan (RPJPN) which requires Indonesia to perform realignment various measures like in the field of natural resource management, human resources, and institutional environment. ${ }^{21}$

In the framework of regional development planning process on the environment, the regional administration composed of regional development planning as a unit in the national development planning and regional development plans prepared by provincial, district/city in accordance with the authority. Regional development plans several preparations include: first, long-term regional development plan (RP JP area) for a period of 20 (twenty) years of which contains the vision, mission, and direction of regional development, which refers to the national RPJP (Law 17 of 2007 on National Long Term Development Plan 2005 - 2025); and

18 Brian J Preston, "The influence of climate change litigation on governments and the private sector", Climate Law, Vol. 2, 2011, p. 502.

19 Van Buuren, Et.Al, "Towards Adaptive Spatial Planning for Climate Change: Balancing Between Robustness and Flexibility", JEEPL, Vol. 10 No. 1, 2013, p. 34.

20 Article 3 Act. Number. 26 Year 2007 on Spatial Planning.

21 Annex Act. Number 17 year 2007 on National Long-Term Development Plan. second, medium-term development plan, hereinafter referred RPJM local area for a period of 5 (five) years is an interpretation of the vision, mission, and programs that the preparation is guided by regional heads RPJP area with attention to the national Development Plan (vision, mission, and programs of the President).

In order to implement the government's commitment to climate change mitigation efforts, the implementation of the REDD + program as the Indonesian government's commitment to address climate change, one of the important areas in the program is forestry and all business activities within. Based on the State of the World's Forest 2011, Indonesia is a country with the largest forest- $8 \mathrm{t}^{\text {th }}$ in the world, namely 94.432 million ha. However, Indonesia is also a country with the third largest deforestation rate, which is 492,000 hectares per year over the last 10 years. The number is much smaller than the deforestation rate published by Statistics of Indonesia Ministry of Forestry in 2011, which is $832,126.9$ ha per year. Thus, if deforestation persists, it was not until 100 years into the future, Indonesia's forests will be depleted.

A variety causes of deforestation in Indonesia becomes important to immediately look for the solution of various aspects to create a unified system of comprehensive environmental law regarding various kinds of constraints from various aspects including the legal aspects which are not in synchronized and integration of legislation in the field of forestry and other sectors such as mining and plantations, rising problems in the implementation phase, especially in the area. Forestry sector is in the framework of implementing change mitigation as government's commitment to climate change mitigation efforts.

In the concept of environmental protecttion and management, environmental protecttion is basically a shared responsibility of all Indonesian citizens but the state has a duty and responsibility by the constitution. The worsening environmental conditions due to development is not environmentally sounded and sustainable; the state must be able to provide solutions and affirmations of environmental pro- 
tection issues through a variety of efforts including setting clear and unequivocal in legislation both in the constitution, laws legislation or other regulation implementation.

Emissions from land use change, forest and peat fires (Land-Use Change, Forestry/LU $\mathrm{CF}$ and Peat Fire) fluctuate. Further it stated that more than 80 percent emission reduction potential is contained in the forestry sector and peat lands. The sectors that play a role in reducing emissions are generally a matter for local authorities such as air pollution control, protection of the atmosphere, forestry and transportation. Within the scope of local government, environmental control must be implemented by local governments. ${ }^{22}$

Central Kalimantan Province, as a pilot project in the context of climate change, has made efforts for the implementation of the Indonesian government's commitment. Some basic laws and policies have been implemented in order to support these activities including first, President of Republic of Indonesia Instruction Number 10 Year 2011 on New Permit/ License Delays and Improving Governance of Primary Forest and peat land; second, agreement between the Central Kalimantan Province Government with the REDD + Task Force on as a program of the Central Kalimantan Pilot Province for the Implementation of Reduced Emissions from Deforestation and Forest Degradation (REDD +) in Indonesia; and third, Governor Central Kalimantan Regulation 10 Year 2012 of the Regional Strategy and Plan of Action for REDD + Central Kalimantan Province.

In general, the problems of the law aspects of the development of the energy industry in Indonesia legislation and regulations are not harmonious and synchronized. In the development of the energy industries, based on Law 32 Year 2009 on Environmental Protection and Management of any business activity that could potentially effect on the environment are required to have an environmental permit to advance through the process of Environmental Impact Assessment (EIA) and other requirements

22 Ibid. under the laws.

An environmental permit is basis for the issuance of business permit (energy industries). However, of the activities in the development of energy, there are some strictly-regulated rules in terms of energy prices and other rules. In principle, the energy developed has great functionality and benefits to society, but on the other hand this type of activity will not be so attractive to the private (business activities) due to energy prices as well as the management strictly regulated by the government. Other problems are related to regional autonomy. Post-enactment of Law 23 Year 2014 on Regional Government, energy affairs under the authority of each region based on the laws and regulations in force. In the development stage should be set in the long-term development plan in order to get government concern and the business world.

Analyzing from the type of activities of energy such as coal with regard to licensing, it should be based on Law 4 of 2009 on Mineral and Coal. In the law, a business permit coal is at the provincial government, if the mining regions are cross county/city and the authority of the local government where the mining area is located within the territory of a district/city. The mining area settings must be made by the local government tender, giving rise to its own problems. Furthermore, if the mining area is located in the forest and then permit must be submitted to the Government.

National energy policy becomes crucial in providing direction of energy policy, but the regulation of Law 30 Year 2007 on energy requiring energy policy must receive Parliament consent (in the form of laws). Drafting legislation takes a long time because it requires the study (academic paper) and should be encouraged in the national legislation to be enacted. It is also related to the function of national energy council.

\section{Conclusion}

In the Indonesian legal system, a comprehensive approach to the holistic implementation is crucial rule. Basically, the rules concern the 
foundation of all other regulatory environment in the management and protection of the environment. Yet, it is highly influenced by political policies and laws in practice.

In addressing the problem of global climate change, Indonesia in principle has a strong commitment, although based on Kyoto protocol; Indonesia is not a country that has an obligation to reduce greenhouse gas emissions. A variety of opportunities and challenges from within and outside the country must be passed by the Indonesian Government. Implementation of international agreements relating to mitigation and adaptation to climate change in the form of regulation should be harmonious with the development of Indonesia from central to local level within the framework of autonomy.

On the other hand, Indonesia is optimistic in mitigation and adaptation to climate change, to see the opportunities that exist in the law and regulation aspects and the various policies and given regulations. Government policy and some arrangements have existed and continue to be prepared in the context of climate change mitigation and adaptation. Establishment of institutions related to climate change shows Indonesia commitment to overcome it. Synergy between the National Action Plan for Green-house Gas Emission Reduction and other rules regarding climate change with national develop-ment plans with the approach to climate change adaptation is one of the advantages that can facilitate the implementation of various agreements in Indonesia and also optimize international cooperation with regard to climate change mitigation and adaptation.

\section{Suggestion}

The provision of energy is required to solve problem of laws sector in the process of a business activity. Hence, it generally should encourage harmonization of relevant legislation and synchronization in the implementation. In an effort to encourage business activities (public and private sector) interest to be able to invest in the industrial sector, the incentive mechanism can be driven separately to increase business activities and environmentally sustain- able.

Sustainable development as an idealized concept, Indonesia seeks control a wide range of development processes in order to maintain function and sustainability for next generations. Formulating development planning becomes very important for the success of the development and preservation of the interests of the present generation and future generations of the possible influence of global climate change and support energy resilience.

\section{References}

Baaner, Lasse and Hvingel. Line. Spatiality of Environmental Law. Journal for european environmental \& planning law. Vol. 12 No. 2. 2015. Pp. 173-188. DOI: $10.1163 /$ 18760104-01202005;

McHarg, Aileen. "Climate change constitutionalism? Lessons from the United Kingdom. Climate Law. Vol. 2. 2011. Pp. 469-484. DOI 10.3233/CL-2011-047;

Nurlinda, Ida. 2009. Prinsip-Prinsip Pembaruan Agraria "Perspektif Hukum". Jakarta: Rajawali Press;

O’Brian, Kevin J. “The War Against Climate Change and Christian Eco-Justice: Ethical Implications of Martial Rhetoric". Worldviews, Vol. 16. 2012. Pp. 135-153. DOI: 10.1163/156853512X640842;

Preston, Brian J. "The influence of climate change litigation on governments and the private sector". Climate Law, Vol. 2. 2011. Pp. 485-513. DOI: 10.3233/CL-2011048;

Rahmadi, Takdir. 2011. Hukum Lingkungan di Indonesia. Jakarta: PT. Rajagrafindo Persada;

Jat, Ram A. Et.Al. "Evaluating Climate Change Mitigation and Adaptation Potential of Conservation Agriculture in Semi-arid Tropics of Southern India. British" Journal of Environment \& Climate Change. Vol. 5 No. 4. 2015. Pp. 324-338;

Savaresi, Annalisa. "Forests. economics. and climate change". Climate Law. Vol. 2. 2011. Pp. 439-446. DOI: 10.3233/CL-2011044;

Schwarte, Christoph. "The International Law Association's Legal Principles on Climate Change and Climate Liability Under Public International Law". Climate law. Vol. 4. 
2014. Pp. 201-216. DOI: $10.1163 / 187865$ 61-00404001;

van Buuren, Et.Al. “Towards Adaptive Spatial Planning for Climate Change: Balancing Between Robustness and Flexibility", JEEPL. Vol. 10 No. 1. 2013. Pp. 29-53. DOI: 10.1163/18760104-01001;

Westphal, Kenneth R. 'From 'Convention' to 'Ethical Life': Hume's Theory of Justice in Post-Kantian Perspective". Journal of Moral Philosophy. Vol. 7. 2010. Pp. 105132. DOI: $10.1163 / 174046809 \times 125076005$ 12291

Zhao, Yuhong. "Climate Change Mitigation-Law and Policy Development in China". Journal for European Environmental \& Planning Law. Vol. 12. 2015. Pp. 305-326. DOI: 10.1163/18760104-01204005. 